\title{
GUESTHOUSE CATERING FACILITY AS AN EXPERIENCE GENERATOR IN ELECTRONIC COMMUNICATION OF HUNGARIAN RURAL TOURISM SUPPLY
}

\section{A VENDÉGLÁTÁS, MINT ÉLMÉNYGENERÁLÓ A HAZAI FALUSI TURISZTIKAI KÍNÁLAT ELEKTRONIKUS KOMMUNIKÁCIÓJÁBAN}

\author{
Márta Kóródi - Róbertné Bakos \\ Tourism and Catering Department, Business Administration Faculty, John von Neumann University, \\ Hungary
}

\author{
Keywords: \\ rural tourism \\ tourist supply \\ differentiation \\ tourism experience \\ experience management \\ Kulcsszavak: \\ falusi turizmus \\ turisztikai kínálat \\ differenciálás \\ turisztikai élmény \\ élménymenedzsment
}

\begin{abstract}
Based on the model of tourism experience components, the experience basis and experience generators allow the creation of experience promises, the formation of experience imagination and the realization of experience. The catering facilities of rural tourism cannot be considered as a part of the experience basis from the point of view of supply due to the legislative framework i.e. the limited availability of catering services. At the same time, demand considers as an essential supply element the countryside flavours, the tasting of traditional gastronomy in terms of both the endowment and the availability and from the professional point of view, the appearance of a supply element in rural tourism in Hungary is unquestionable. The exploratory research covers the entire range of qualified accommodation based on the FATOSZ (Hungarian National Association of Rural and Agrotourism) electronic communication database, analyses the experience promises based on the aspects developed according to the topic, identifying their experience basis or experience generator characteristics, looking for the relationship between quality and the gastronomic experiences.

Összefoglalás

A turisztikai élményösszetevők modellje alapján az élménybázis és élménygenerálók teszik lehetôvé az élményígéretek megalkotását, az élményképzet kialakulását, valamint az élmény megvalósulását. A falusi turizmus ellátási szolgáltatásai a jogszabályi háttér, vagyis az étkezési jellegü szolgáltatások lehetőségének korlátozottsága miatt nem tekinthetőek az élménybázis részének a kínálat szempontjából, ugyanakkor a kereslet a falusi ízeket, a hagyományos gasztronómia megtapasztalhatóságát mind az adottság, mind az igénybevételi lehetőség szempontjából alapvetőnek tekinti és szakmai szempontból is
\end{abstract}


megkérdőjelezhetetlen a kínálati elem megjelenése a hazai falusi turizmusban. A feltáró kutatás a FATOSZ elektronikus kommunikációs adatbázisa alapján a minősített szálláshelyek teljes körét lefedi, a témának megfelelően kialakitott szempontsor alapján elemzi az élményígéreteket, beazonosítva azok élménybázis vagy élménygenerátor típusú jellemzőit, összefüggést keresve a minőség és a gasztronómiai élménykínálat között.

\section{Introduction}

Rural tourism can be classified as cultural as well as heritage tourism, on the one hand, as an attraction based on past values, and on the other hand as a service that intensively mediates the local culture. The product of the rural tourism is a complex package of services, with attraction factors, touristic infrastructure and superstructure elements. Therefore, it is not the same as village accommodation provision, however in fact the visitors expect much more from traditional accommodation providers, who do not influence actively the tourists' program, they mostly just offer leisure time activities. The host image is closer to the village accommodation hosts, familiarizing themselves with the local lifestyle, traditions and customs, including gastronomy. Hospitality as an element of choice and a desire to create connections, are motivations for an encounter with common cooking or having a collective meal.

The scarcity of resources can also be interpreted in rural tourism, but not always due to physical scarcity, but due to a lack of resource recognition. The resources usually considered to be worthless in a village (homemade gastronomy in the countryside) can be made marketable and can be sold at a good value for money. Experience-creation is based on the previous experience of the tourist, on their knowledge and on the communication of the accommodation with a promise of experience provision. The experiences created by the previously mentioned factors is expected to be realized during the trip, and the intensity of the fulfillment will cause satisfaction or disappointment. Experience generation takes place on an existing narrower or broader experience base. As an experience, the tourist considers the feeling and perceptions that he / she believes have happened to him / herself at a point of time and that this happening has been a unique event, and has not been experienced by larger crowds, nor can circumstances be provided more or more repeatedly. Due to the scale and scope of rural tourism, it is also suitable for personal services. The generated content of experience distinguishes rural tourism service providers based on the nearly identical experience base (nature-centric, human-centric), which can be identified with cases of selecting between similar services [8].

Due to the nature of the tourism as a product, the pre-planned service package can be complemented on site, as the elements of experience in the rural tourism that meet the needs are usually recognized by the host and can particularly complete the travel experience. Information provided by displaying high-end supply elements support the process of choice. By communicating convenience and personal experience services, the value-for-money rate perceived by the tourist will be more favorable. Value management of tourism means the management of the limitation of accessibility (personality and on-site consumption), the atmosphere of the site, the guest-service provider and the guest-guest relationships [6]. Based on the personal nature of the factors, rural tourism is a higher hierarchy type of tourism for some guest types. This is why rural tourism can turn to a more active experience generator, instead of remaining a simple experience transmitter [10].

Also in case of rural tourism, the experience idea generated by the experience promise is one of the levels of the two-level competitive advantage [5], meaning the observation of quality and uniqueness, what influences travel decisions. The other level is originated from the postjourney image, the correspondence between satisfaction, experience and intensity of experience, detection of the "wow" experience (satisfying latent needs). However, as every tourist is different, an alternative way of forming the experience generation is needed, which means expanding service features to meet potential value expectations.

In the typology of experiences, the experiences of the guests of rural tourism can be described as the intersection of the followings: experiences with the new situation and new impressions, encounter experiences, experience of discovery, individual challenge experiences, 
experiences with nature, experiences with pleasures, experiences connected to the change of age [4].

Four of the seven tourist types of Smith [2] can be identified in rural tourism from the point of view of potential participation. Exploring tourists perfectly adapt, they are in direct contact with local residents, avoiding tourist centers. For them, offering authentic supply items is sufficient. The elite tourist is similar to the previous one in behavior, but is less determined. Emphasizing unique supply elements is needed to persuade them. The off-beat tourist adapts well. Although he prefers to take part in group tourist trips, he can get in touch with the locals. Experience-rich thematic programs are made for them. The almost-mass-tourist type is looking for convenience services, but they can temporarily accept their shortcomings. With impulsive communication and attractions, their willingness to focus on local values can be exploited.

Rural tourism is therefore a complex and cultural offer. Apart from lodging, hiking, good healing, horseback riding and camping, also gastronomy is present with own food and drinks [9].

The offer of rural tourism gastronomy (food, drinks, joint activities, events) is able to fulfill individualization needs. Food tasting, cooking presentation, commonly preparing food provide excellent opportunities for individual activities. Selection of the stuffing, formatting options, decoration, defining the materials to be used, a simple meal or a cake can become personal, which, among other things, provides a sense of experience, not only trial. This is how a mid-level mass-service can become a high-quality, unique program item. Preparation and tasting meals which are included in the collection of Hungaricums and in the Hungarian Value Depository can also be a unique experience for the tourists. Involving the tourists in the preparation also offers program facilities for rural tourism service providers even in those areas, where the typical local food is only a part of the local habits.

The village guest table service means presenting activities related to food and gastronomic traditions and offering food in a rural, farmhouse or village environment for onsite consumption. Homely, direct catering, food preparation service.

The activity is strictly controlled in terms of its raw material, control and quantity, and its food preparation program must also be reported. Only on-site consumption is possible, take-away is not allowed. Selling 'pálinka' and wine is not allowed in glasses. But if the farmer as a "small producer" has paid the excise tax, has bottled the distillate, has put tax-stamp on the bottle, the 'pálinka' can also be sold for on-site consumption, tasting and bottled take-away. For the sale of wine, the simplified tax warehouse has to be obtained by the farmer. In both cases sales can take place without a business relationship [3].

\section{Materials and methods}

The individuality and experience content of the service providers was assessed on the basis of the FATOSZ (Hungarian National Association of Rural and Agrotourism) qualified accommodation database [7]. One of the functions of the national certification mark "sunflower" is the indication and guarantee of the quality of service for the tourist. Rural tourism, in the imagination of the guests, includes the display, experience of the countryside gastronomy and the "hospitality" (of course, for some offset), so the expectation towards the highest rating is that the service will be a real high-level experience. One of the goals is to promote conscious consumer behavior with supporting the selection, but the consumer imagination and the regulations do not fit properly in this respect. Rural accommodations belong to the other accommodations category (Government Decree 239/2009 (X.20.)), which are basically arranged for the self-sufficiency of tourists. Coffee and tea cooking facilities, equipment for the preparation of breakfast-style dishes and equipment (cooker, sink, table, chair, tableware) should be provided for guests with separate refrigerator use.

The additional service to be provided by the certification service providers for the use of sunflower trademarks extends to premises and material conditions. What belongs to a onesunflower level: providing a kitchenette to guests with utensils, cooking utensils and equipment in accordance with the number of beds, wiping cloths for dishwashing and cleaning 
the floor. The higher quality of the sunflower certification can be the common kitchen use, the separate kitchen, and the built-in kitchen. In the case of devices, the kitchen cabinet, the microwave oven and the toaster are named for the three-sunflower standard, in the highest category it is only supplemented by the kettle, and - in case of a guest house instead of room - also with the stove instead of the hob. The dining area must be provided from the kitchen to the dining room, through the lounge to the separate dining room. For the catering service, each category has been labeled "self-sufficiency or on request", which can be either village guest desk service, or a licensed catering service, if the guest wishes to be catered for even occasionally. Or the provider can take the risk of unauthorized meals and the consequences of illegality. Service providers must provide optional services based on their capabilities at 20, 50,70 and 100 points per sunflower respectively. Optional services include the preparation and supply of regional dishes, local production (problematic, if not small-scale, host), wine cellar, 'pálinka' tasting, with at least 3 kinds of regional drinks (consumption and distribution of homemade offerings of both beverage groups are complicated because of permissions), gentle or organic food, children's menu, herbal teas, furnace, summer kitchen, outdoor cooking stove. In the case of tangible equipment, the dishwasher and the coffee machine are optional extra services.

There are 782 service providers in the database of the professional organization (two of them are not qualified, only registered). As these provide the most complex services and are comparable, other types of service providers have not been selected for inclusion in the rated population. The registered features are the accommodation's name, address, website, or the host's e-mail address, number of rooms and capacity. $87.69 \%$ of the accommodations have four, $10.64 \%$ three, $1.67 \%$ have two sunflowers, while one-sunflower rating has not been initiated by service providers. Data population cleaning was based on the availability of electronic communications, because the knowledge of the service offer was important for the rating of the experience content, either through standalone or collecting websites. If the provider also has a Facebook page, the information contained therein was included as a supplement, and also the deviation from official communication could be examined. After cleaning, the total sample size was 746 , of which $87.94 \%, 10.46 \%$ and $1.61 \%$ were the three categories.

The information on the supply has been examined from six aspects: breakfast, main meals, other meals, gastro-activity options, gastronomic events and drinks. The evaluation happened on a six-grade scale: received o ratings, if the given supply element was not provided, 1 qualified the incomplete or weak supply element, or appeared only as a reference in communication. It received 2 values if the item appeared as a specific, but generic offer, and can be rated as 3 if it is a rural display. If it is definitely rustic, it deserves a value of 4 , the highest score, 5 was given to supply elements with high rustic experience.

\section{Results}

In terms of electronic communication, the difference between the population and the sample indicate the relationship between the categories and accessibility. The higher the number of sunflowers was, the greater was the availability of electronic content, $10(2 \mathrm{~N}), 6$ $(3 \mathrm{~N})$, and $4(4 \mathrm{~N})$ percent of the categories are not available communication platform. The evaluations received were summarized in three aspects. On the one hand, the values of the aspects could be averaged, on the other hand, the service providers could obtain an average score from the points of view, and last, but not least, the comments made by the evaluators provide an opportunity to characterize the elements of experience.

In terms of averaging (Figure 1), the relationship between experience content and quality has been confirmed, although the difference between categories does not represent a difference in magnitude. The two sunflower groups scored the highest average rating for the main meals, the three sunflower groups on average for breakfast and drink, while the four sunflowers won on the gastro-activity and gastronomic offer. The weaknesses of the two sunflowers are in the drink supply, in the three sunflowers, in the gastro-activity and in the other meals, while in the four sunflowers, the drink offer. 
In terms of the three categories examined, the host's average points also increase with the level of quality (Figure 2) the more sunflowers a guest house had, the higher average it could earn.

Based on experience, outstanding hosts could be found in all categories, presumably due to the fact that a small producer, farmer or host is the owner himself. In addition to the urban amenities and comfort of the house, the distant owners do not offer gastro-activities, and the experience of participation in rural tourism is undermined. The rural character does not appear at such resource-based service providers. At the same time, there are many good practices from cutting pigs through wine tasting to countless possible uses of ovens.

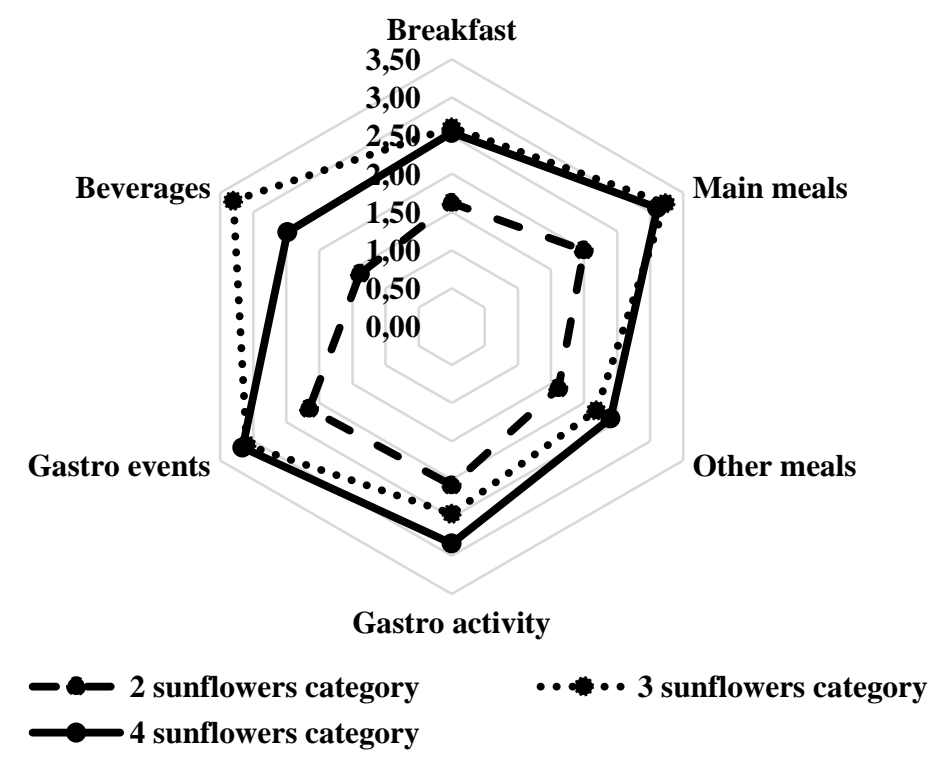

Figure 1 Average position of gastronomic experience supply elements in rural tourism by classification categories

Source: Own editing

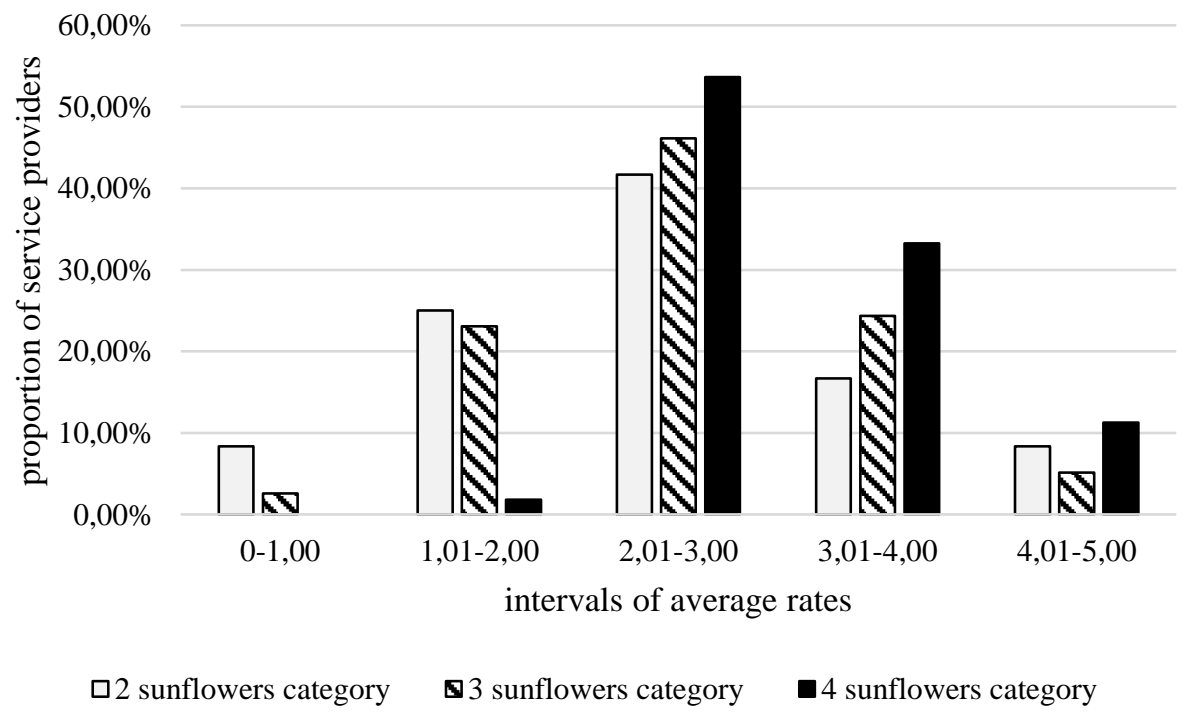

Figure 2 Proportion of average evaluation of service providers in rural tourism by classification categories 
Source: Own editing

\section{Conclusions}

The lack of uniform interpretation of rural tourism is the starting point of many problems. Own food and beverage offerings can also be a great experience if the host does not produce the majority of the raw materials (as defined in the local product regulation), but also purchases raw materials for the guest's food from neighbors, local producers. However, in most cases a simple "dödölle" dinner would be a resale activity, which would also require licensing for catering activities, which is not a good thing because of the regularity and frequency of earnings. For this reason, the services listed on the websites are contradictory, e.g. there is no food-supply and still, some photos show the common food preparation and meals. It would be advisable to rethink the regulation of rural hospitality to increase the efficiency of the value transfer.

\section{Acknowledgements}

This research is supported by EFOP-3.6.1-16-2016-00oo6 "The development and enhancement of the research potential at John von Neumann University" project. The Project is supported by the Hungarian Government and co-financed by the European Social Fund.

\section{Bibliographical References}

[1] Fehér, I. - Kóródi, M. (2008): A vidéki turizmus fejlesztése. Szaktudás Kiadó Ház, Budapest

[2] Gonda, T. (2016): A turisztikai termékfejlesztés elméleti alapjai. PTE KPVK, Pécs, pp. 11.

[3] Kóródi, M. (2016): Miértek és hogyanok a helyi termékek forgalmazásáról - különös tekintettel a turisztikai hasznosításra - három ország öt településének példája alapján. In: Gradus, 3 (2) pp. 196-207.

[4] Kovács, D. (2014): Élmény, élménygazdaság, élménytársadalom és turizmus. In: Turizmus Bulletin, 16 (3-4) pp. 40-48.

[5] Levytskyy, A (2015): Competitiveness of tourism product. Evaluation and approaches to provision. In: Journal of Geography, Politics and Society, 2 pp. 7-18. Available: https://www.ceeol.com/search/articledetail?id=538204 [Accessed: 08-09-2018]

[6] Lőrincz, K. - Sulyok, J. (Ed.) (2017): Turizmusmarketing. Akadémiai, Budapest, Available: https://shibboleth.mersz.org/?xmlazonosito=dj277tm_100_p1\#dj277tm_100_p1 [Accessed 08-09-2018]

[7] Nemzeti Tanúsító Védjegy. Tudnivalók a védjegyről. Minősítési követelmények. FATOSZ Available: http://www.fatosz.eu/ftp/minimalis alapkovetelmenyek.pdf [Accessed 16-09-2018]

[8] Rekettye, G. - Hetesi, E. (2017): Kínálatmenedzsment. Akadémiai, Budapest, Available: https://shibboleth.mersz.org/?xmlazonosito=dj228km_1_p1\#dj228km_1_p1 [Accessed: 07-09-2018]

[9] Szabó, G. (2011) A falusi turizmus termékei és termékspecializációi.

Available:http://www.eturizmus.pte.hu/szakmaianyagok/turisztikai\%20term\%c3\%agktervez\%c3\%a9s\%20\%c3 \%a9s\%20fejleszt\%c3\%a9s/book.html\#d6e318 [Accessed: 30-08-2018]

[10] Zátori, A. (2014): A turisztikai élményteremtés koncepciói a gyakorlatban. In: Turizmus Bulletin, 16 (3-4) pp.49-58. 